\title{
Isolation, cell culture and immunocytochemical characterization of oviduct epithelial cells of the cow
}

\author{
M. S. Joshi \\ Department of Anatomy, University of North Dakota School of Medicine, Grand Forks, ND 58202. \\ U.S.A.
}

\begin{abstract}
Summary. Incubation of cow oviducts flushed with $0.1 \mathrm{mg}$ collagenase $/ \mathrm{ml}$, for $90 \mathrm{~min}$ helped to dislodge large numbers of ciliated and secretory cells. About $90-95 \%$ of the isolated epithelial cells were viable. The epithelial cells suspended in DMEM:F-12 $+10 \%$ serum attached to the plastic culture dish in $18-20 \mathrm{~h}$ after seeding. The ciliated cells which attached to the plastic dish lost their cilia after 4-5 days in culture. The attached cells, which proliferated to form a confluent monolayer 8-10 days after seeding in a $35-\mathrm{mm}$ dish, could be subcultured at least 3 successive times. Some cell aggregates which did not attach to the culture dish proliferated into floating balls of cells. The ciliated cells in the unattached floating colonies maintained the ciliary movement for 9-10 days in the same culture medium. The primary cultures of the ciliated and the secretory cells maintained most of the histoarchitecture observed in intact epithelium. The secretory cells maintained their secretory activity of specific proteins in culture as indicated by immunocytology. The cultured cells contained keratin, a specific cytoskeletal component of epithelial cells.
\end{abstract}

Keywords: oviduct epithelium; cell-culture; microscopy; immunocytology; cow

\section{Introduction}

The oviduct plays an important role in the reproductive process. It is considered to provide a conducive environment for gamete maturation, gamete transport, fertilization and embryo development (Chang, 1951; Kille \& Hamner, 1973; Shapiro et al., 1974; Gaunt, 1985; Kapur \& Johnson, 1985). The luminal contents of the oviduct are contributed by selective transudation of serum components (Feigelson \& Kay, 1972; Oliphant et al., 1978) and specific secretory products of oviduct epithelium (Urzua et al., 1970; Stone et al., 1980). The study of specific secretory products in rabbits (Oliphant et al., 1984; Hyde \& Black, 1986) and in baboons (Fazleabas \& Verhage, 1986) has been attempted by using oviduct explants. The proliferation, ciliation and the secretory process of the oviduct epithelium are influenced by the ovarian hormones (Fredricsson, 1959; McDaniel $e t$ al., 1968; Brenner, 1969; Odor et al., 1983). Oviduct secretions can be best studied independently of contributions from the serum by growing the epithelial cells in vitro in controlled culture conditions. There have been some attempts to culture explants of the oviduct of rabbits (Nilsson \& Helistrom, 1957; Odor \& Blandau, 1985), of fetal mice (Rumery, 1969), of pigs (Boullant \& Greig, 1973) and of cows (Witkowska, 1979a b). Preliminary findings on the cell culture of bovine oviduct epithelial cells on plastic (Joshi, 1986) and on reconstituted basement membrane (Joshi, 1987) have been reported. The studies of Witkowska $(1979 a, b)$ and Joshi $(1986,1987)$ did not attempt to study the specific morphological and functional characteristics of the epithelial cells growing in vitro. In this report a simple method of isolation and cell culture of oviduct epithelial cells from cows is described and the ciliated and secretory cells growing in cell culture were examined by electron microscopic study and immunocytochemistry. 


\section{Materials and Methods}

Animal material. Uteri and ovaries of cows were obtained fresh from the slaughter house (Held Beef Industries, Fargo, ND, U.S.A.). Oviducts that were associated with ovaries in the follicular stage of the cycle were selected for the study.

Isolation of the epithelial cells. The oviducts were dissected from the uterus and freed from the associated mesentery, major blood vessels and fat. The fimbria with preampullae were removed. The ampulla and isthmus were saved for the study. Each portion of the oviduct was flushed with $10 \mathrm{ml} \mathrm{Ca}^{2+}$ - and $\mathrm{Mg}^{2+}$-free Hank's balanced salt solution (HBSS; Gibco, Grand Island, NY, U.S.A.) and then with $5 \mathrm{ml} 0.1 \%$ collagenase ( $148 \mathrm{u} / \mathrm{mg}$; Gibco) in HBSS. The oviducts were then incubated at $37^{\circ} \mathrm{C}$ in an atmosphere of $95 \%$ air and $5 \% \mathrm{CO}_{2}$ for $90 \mathrm{~min}$ with the enzyme solution retained in the lumen of the oviducal tubes. At the end of incubation the oviducts were flushed with $10 \mathrm{ml}$ minimum essential medium (MEM, Gibco) buffered to pH 7.4 with Hepes (Sigma, St Louis, MO, U.S.A.). The flushed cells were centrifuged at $960 \mathrm{~g}$ for $5 \mathrm{~min}$ in a clinical centrifuge and the cellular sediment was resuspended in $1 \mathrm{ml}$ MEM. The viability studies were done by estimating trypan blue dye exclusion. The counting of the isolated cells was done using a haemocytometer.

Histological preparations. Freshly obtained ampullae and isthmi were trimmed of fat and the lumen was flushed with Karnovsky's fixative (Karnovsky, 1965). The oviducts were then cut into 2-mm pieces and suspended in the same fixative overnight in a refrigerator. The tissue pieces were rinsed with cacodylate buffer $\mathrm{pH} 7 \cdot 4$, post-fixed in $2 \%$ osmium tetroxide (Tousimis, Rockville, MD, U.S.A.) dehydrated and embedded in an Epon-Araldite mixture (50:50 $\mathrm{v} / \mathrm{v}$ ) for thick and thin sectioning.

For transmission electron microscopy of the subconfluent cultured cells, the procedure was followed as described by Joshi (1985). In summary, the culture dishes were rinsed with phosphate-buffered saline (PBS), fixed in Karnovsky's fixative, post-fixed in $2 \%$ osmium tetroxide, dehydrated, infiltrated in alcohol-Epon mixture and embedded in Epon. The plastic dish was pulled away from the Epon, leaving the cells embedded in Epon. The vertical sections passing through the surface facing the medium and the surface facing the plastic as well as oblique sections in the horizontal plane were stained with $2 \%$ uranyl acetate and $0.2 \%$ lead citrate for viewing on a transmission electron microscope.

For scanning electron microscopy of the isolated free cells, the cells were deposited on the Unipore filter by using a tuberculin syringe. The Unipore filter with the adhered cells was processed for scanning electron microscopy. The cells were fixed in Karnovsky's (1965) fixative, post-fixed in $2 \%$ osmium tetroxide, dehydrated, critical point dried and coated with gold/palladium (60/40). The cells were observed on an Hitachi S800 scanning electron microscope.

Cell culture of epithelial cells. The isolated epithelial cells flushed from the ampulla or isthmus were suspended in Dulbecco's modified Eagle's medium and Ham's F12 (DMEM:F12; Gibco, 50:50 v/v) containing 10\% fetal calf serum or horse serum (Gibco), $5 \mu \mathrm{g}$ insulin $/ \mathrm{ml}, 5 \mu \mathrm{g}$ transferin $/ \mathrm{ml}, 5 \mathrm{ng}$ selenium $/ \mathrm{ml}$ (Sigma), $100 \mu \mathrm{g} \mathrm{streptomycin} / \mathrm{ml}$, 100 i.u. penicillin $/ \mathrm{ml}$ and $2.5 \mu \mathrm{g}$ fungizone $/ \mathrm{ml}$ (Gibco) to yield approximately $1 \times 10^{6} \mathrm{cell} / \mathrm{s} / \mathrm{ml}$. Then $1 \mathrm{ml}$ of the cell mixture was seeded in a $35-\mathrm{mm}$ culture dish and incubated at $37^{\circ} \mathrm{C}$ in an atmosphere of $95 \%$ air and $5 \% \mathrm{CO}_{2}$. The culture medium was changed every 2 days. The growth of the cells was observed on a phase-contrast microscope. Subculturing of the confluent cultures was done by detaching the cells from the dish using $0 \cdot 25 \%$ trypsin (Sigma) and $3 \mathrm{~mm}$-EDTA at $37^{\circ} \mathrm{C}$ and mechanically dispersing the cells with a sterile transfer pipette. The detached cells were centrifuged, mixed with DMEM:F12 + 10\% serum and reseeded. Cells from one confluent dish were seeded into 3 or 4 culture dishes.

Preparation of antiserum to secretory proteins of bovine oviduct. The oviducts of 8 cows were removed carefully from uteri and trimmed of the mesentery, major blood vessels and fat. Each oviduct (with ampulla and isthmus) was flushed with $10 \mathrm{ml}$ phosphate-buffered saline (PBS). The pooled flush was centrifuged at $7000 \mathrm{~g}$ for $15 \mathrm{~min}$ at $4^{\circ} \mathrm{C}$ to remove the cell debris and mucus clot. The supernatant was dialysed against PBS in a cold room for $48 \mathrm{~h}$. The retentate was concentrated by ultrafiltration to $4 \mathrm{ml}$ by an Amicon PM 10 filter (Amicon, MA, U.S.A.). The protein in the concentrated oviduct fluid was $5 \mathrm{mg} / \mathrm{ml}$ using bovine serum albumin as standard protein (Lowry $e t$ al., 1951). Concentrated oviduct fluid $(0.8 \mathrm{ml})$ was emulsified with an equal volume of complete Freund's adjuvant and injected intramuscularly into a rabbit. At 20 days after the intramuscular injection the first booster injection of $0.35 \mathrm{ml}$ of the concentrated oviduct fluid was administered into the marginal ear vein. Two more booster injections were administered at 4-week intervals. At 1 week after each booster injection, the antiserum was collected. The antiserum obtained after removal of the clot was divided into 5 -ml samples and stored at $-20^{\circ} \mathrm{C}$. Before use of the antiserum for immunocytology and immunoblot it was repeatedly absorbed with lyophilized calf serum (Gibco) until no precipitate was observed. Different dilutions of the absorbed antiserum were tested against the material flushed from the oviduct and against bovine blood serum by Oucterlony's double-diffusion test. The second and third bleeds which provided strong immunoprecipitin lines against oviduct fluid proteins but not against serum were pooled.

Immunofluorescent tracing of oviduct secretory proteins. Immunofluorescent tracing of oviduct secretory proteins was done on $8-\mu \mathrm{m}$ cryostat sections, $6 \mu \mathrm{m}$ paraffin-wax sections, $1-2 \mu \mathrm{m}$ methacrylate sections of freshly obtained oviduct tissue and on subconfluent primary cell cultures. Pieces of oviduct tissue $(4-5 \mathrm{~mm})$ were fixed overnight in Bouin's fixative, and processed for embedding in paraffin wax or methacrylate (Polysciences, JB 4 kit). The methacrylate and deparaffinized-hydrated sections were first washed with PBS and layered with a 1:10 dilution (in PBS containing $1 \%$ normal goat serum; PBS-NGS) of primary antiserum which was filtered through a $0.2 \mu \mathrm{m}$ filter. 
The control and experimental slides were kept in separate humid chambers and incubated overnight in the refrigerator. At the end of the incubation the sections were washed with PBS-NGS 5 times and the control and experimental slides were incubated with a 1:10 dilution (in PBS-NGS) of goat anti-rabbit IgG conjugated to fluorescene isothiocyanate (Miles, Naperville, IL, U.S.A.) for $\mathrm{I}$ h at room temperature. The secondary antibody was washed 5 times with PBS and the sections covered with a drop of $95 \%$ glycerol in PBS and a coverslip. The immunofluorescence was observed under Leitz Dialux 20 equipped with epifluorescence. The cryostat sections of oviduct were fixed for $5 \mathrm{~min}$ in cold absolute methanol, washed with PBS and processed for immunocytology as described above.

For immunocytology of the secretory proteins in cultured cells, the cells were washed twice with cold PBS and later incubated for $10 \mathrm{~min}$ in PBS containing $0.1 \%$ Triton X-100. The cells were again washed in PBS and fixed for $5 \mathrm{~min}$ in cold absolute methanol. After fixation, the cells were rinsed 3 times with PBS-NGS at room temperature. Further immunocytological tracing was done using the same protocol used for sections of the oviduct tissue.

As control, a monolayer of corneal endothelial cells from cows was processed as for immunofluorescent tracing of the oviduct secretory proteins.

Immunofluorescent tracing of keratin in the cultured cells. Immunofluorescent tracing of keratin in cell cultures was done according to the procedure described by Olson et al. (1983). For this study a 1:10 dilution of guinea-pig antibovine keratin (Miles) was used as primary antiserum and a 1:10 dilution of goat anti-guinea-pig IgG was coupled to fluorescein (Sigma) as secondary antibody.

Immunoblot studies. Polyacrylamide gel electrophoresis (PAGE) of calf serum and bovine oviduct fluid in the presence of sodium dodecyl sulphate was done according to the method described by Laemmli (1970) using $5 \%$ sample gel and $10 \%$ separation gel. One set of electrophoresed samples and the molecular weight standards (Pharmacia) were stained with Coomassie blue to analyse the protein components in the calf serum and in oviduct fluid. The gel containing the other two sets of electrophoresed samples was kept in contact with nitrocellulose paper and electrophoresed overnight at $25 \mathrm{~mA}$ constant current to transfer the proteins onto the nitrocellulose paper. At the end of electrophoresis the two sets of transblots were processed for immunostaining. The paper was first incubated for $40 \mathrm{~min}$ in $5 \%$ fat-free milk powder in Tris-buffered saline, $\mathrm{pH} \mathrm{7.4}$ (Medium B). The papers were then incubated in normal rabbit serum (control, 1:10 dilution) or rabbit antiserum against oviduct fluid (experimental, dilution 1:10) for $2 \mathrm{~h}$. The dilutions of the primary as well as the secondary antibodies were made in Medium B. The primary antiserum or normal rabbit serum was washed 5 times with Medium B, 5 min each, and both the control and experimental strips of paper were incubated with a 1:100 dilution of peroxidase conjugated anti-rabbit IgG (Cappel, PA, U.S.A.) for $1 \mathrm{~h}$. The secondary antibody was washed similarly from the paper strips with Medium B and colour reaction was obtained using 4-chloro-! -naphthol (Sigma) and hydrogen peroxide in TBS.

\section{Results}

\section{Electron microscopy of the intact oviduct}

The epithelium of the isthmus and ampulla contained predominantly two types of cells, the ciliated cells and non-ciliated secretory cells (Fig. 1). The histoarchitecture of the epithelium was similar to that described by previous authors (Bjorkman \& Fredricsson, 1961; Dickey \& Hill, 1974; Nayak \& Wu, 1975; Uhrin, 1983; Uhrin \& Kliment, 1983a b). The ciliated cells extended from the basal lamina to the lumen, with cilia intermingled with a few microvilli uniformly distributed at the luminal end (Fig. 1). The ciliated cell contained typically a large number of mitochondria distributed throughout the cell cytoplasm. The supranuclear Golgi complex and rough endoplasmic reticulum were occasionally seen in these cells. They contained a number of smooth vesicles and polyribosomes. The secretory cells also extended from the basal lamina to the lumen with irregularly scattered microvilli on the plasma membrane exposed to the lumen (Fig. 1). Some of the secretory cells had dome-like projections within the lumen. The cytoplasm of the secretory cell contained extensive rough endoplasmic reticulum and polyribosomes with fewer mitochondria. Several foci of the Golgi complex containing 4-5 stacks of cisternae were observed in the supranuclear cytoplasm (Fig. 1). A number of secretory vesicles of different sizes, shapes and density were encountered at the apical portion of the cytoplasm. The content of the secretory vesicles varied from very light staining to dense staining material. Several of the vesicles contained material possessing concentric lamellae.

\section{Isolation and cell culture of the epithelial cells}

Incubation of the ampulla or isthmus after the flushing of the lumen with $0 \cdot 1 \%$ collagenase for $90 \mathrm{~min}$ at $37^{\circ} \mathrm{C}$ released large numbers of epithelial cells. The flushed cells contained ciliated and 


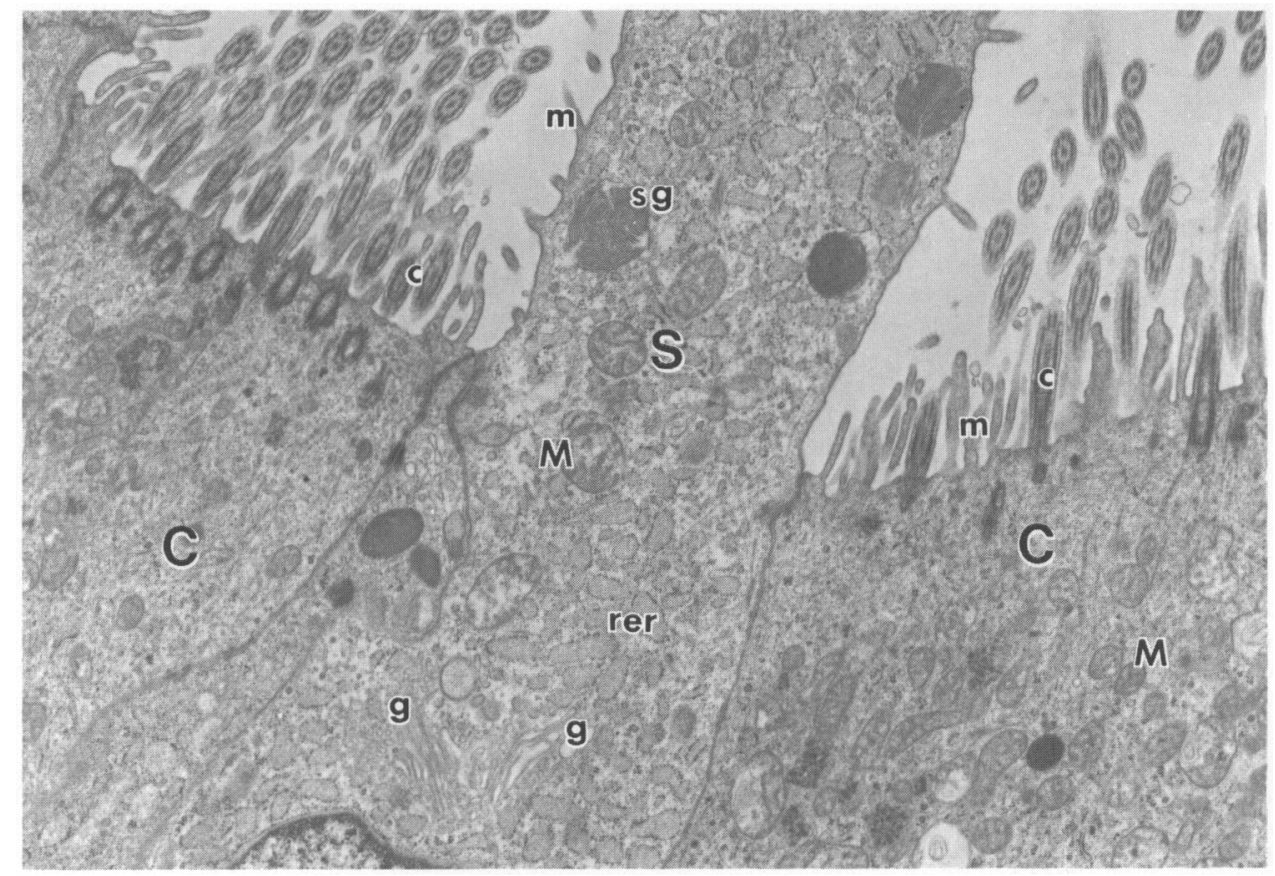

Fig. 1. Electron micrograph of a section through the apical portion of the epithelium of the cow ampulla showing the ciliated cells $(\mathrm{C})$, and secretory cells $(\mathrm{S})$. Note the abundance of dilated rough endoplasmic reticulum (rer), well developed Golgi complex (g), and prominent secretory granules (sg) in the secretory cells. The contents of some of the secretory granules have a lamellar arrangement. c, cilia; m, microvilli; M, mitochondria. $\times 9500$.
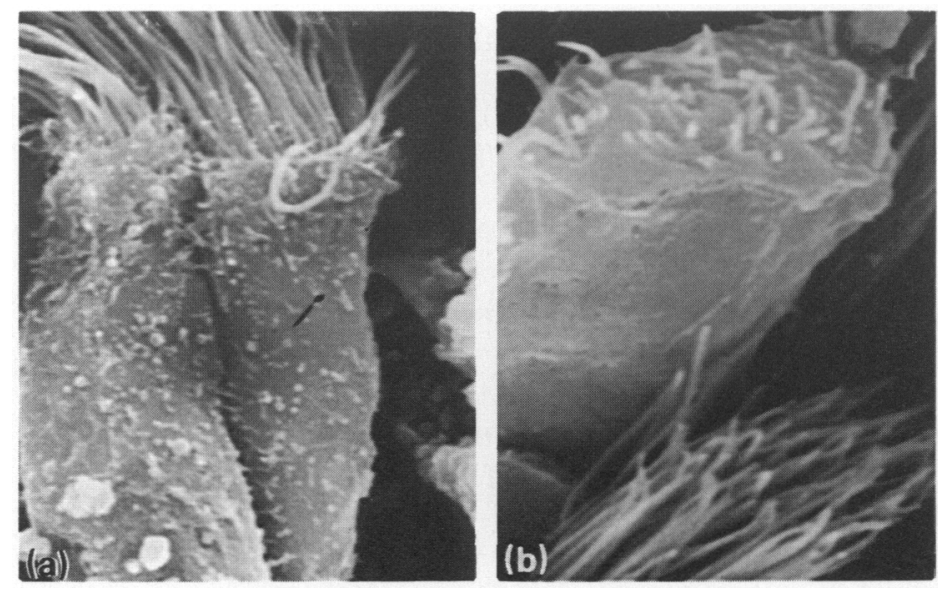

Fig. 2. Scanning electron micrographs of (a) isolated ciliated cells, $\times 3500$; and (b) an isolated secretory cell, $\times 4500$.

secretory cells as observed on the scanning electron microscope (Fig. 2). The trypan blue exclusion studies indicated that $90-95 \%$ of the isolated epithelial cells were viable. The isolated cells contained 

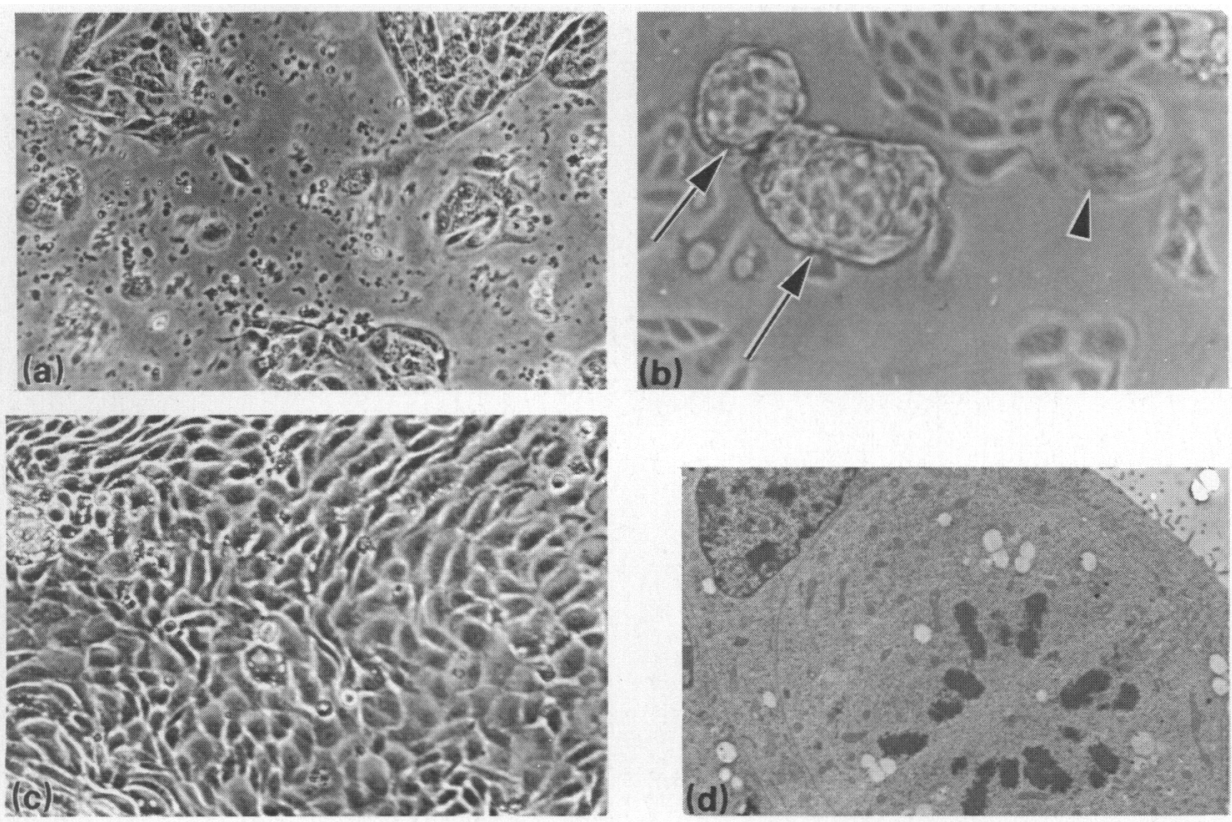

Fig. 3. Phase-contrast micrographs of the cell cultures of bovine oviduct epithelium (ampulla): (a) 2-day culture, (b) 5-day culture. Note the two balls of unattached epithelial cells (arrow). These cell colonies often showed active ciliary movement. The arrowhead indicates the cell colony actively spinning in the medium. (c) A 10-day cell culture and (d) an electron micrograph of a cell demonstrating mitotic activity. a, $\times 120 ; \mathrm{b}, \times 150 ; \mathrm{c}, \times 150 ; \mathrm{d}, \times 2100$.

a large number of individual epithelial cells and several small groups of aggregated epithelial cells. After seeding of the isolated cells suspended in DMEM:F12 $+10 \%$ serum and insulintransferin-selenium in a $35-\mathrm{mm}$ plastic culture dish, several clusters of cell colonies were formed by individual cells and cell clumps within 18-20 h (Fig. 3a). All the colonies displayed a typical epithelial appearance with highly packed polygonal or elongated cells. The young colonies contained ciliated cells as recognized by the movement of the cilia for the first 3-4 days of culture, but lost the ciliary beating completely by the 5 th day of the culture. A few cells which did not attach to the plastic dish remained floating in the culture medium with active ciliary movement. These unattached cell clusters, which survived 3 or 4 changes of the nutrient medium, grew into balls of cells often actively spinning in the culture medium (Fig. 3b). The ciliary activity of the ciliated cells in the floating balls was maintained for 8-10 days. The cells which attached to the plastic dish proliferated, as indicated by mitotic cells (Fig. 3d), and became confluent in 10-12 days after seeding (Fig. 3c). The confluent cells could be detached from the plastic and subcultured at least 3 consecutive times without any. adverse morphological changes as observed by phase-contrast microscopy. The cells proliferated equally well in fetal calf serum and in horse serum.

\section{Electron microscopy of the cultured cells}

The transmission electron microscopic appearance of the epithelial cell cultures of ampulla and isthmus did not differ greatly from each other. The electron microscopic section passing through the plasma membrane exposed to the medium and the plasma membrane facing the plastic dish indicated that the epithelial cells maintained polarity with the presence of prominent microvilli at 


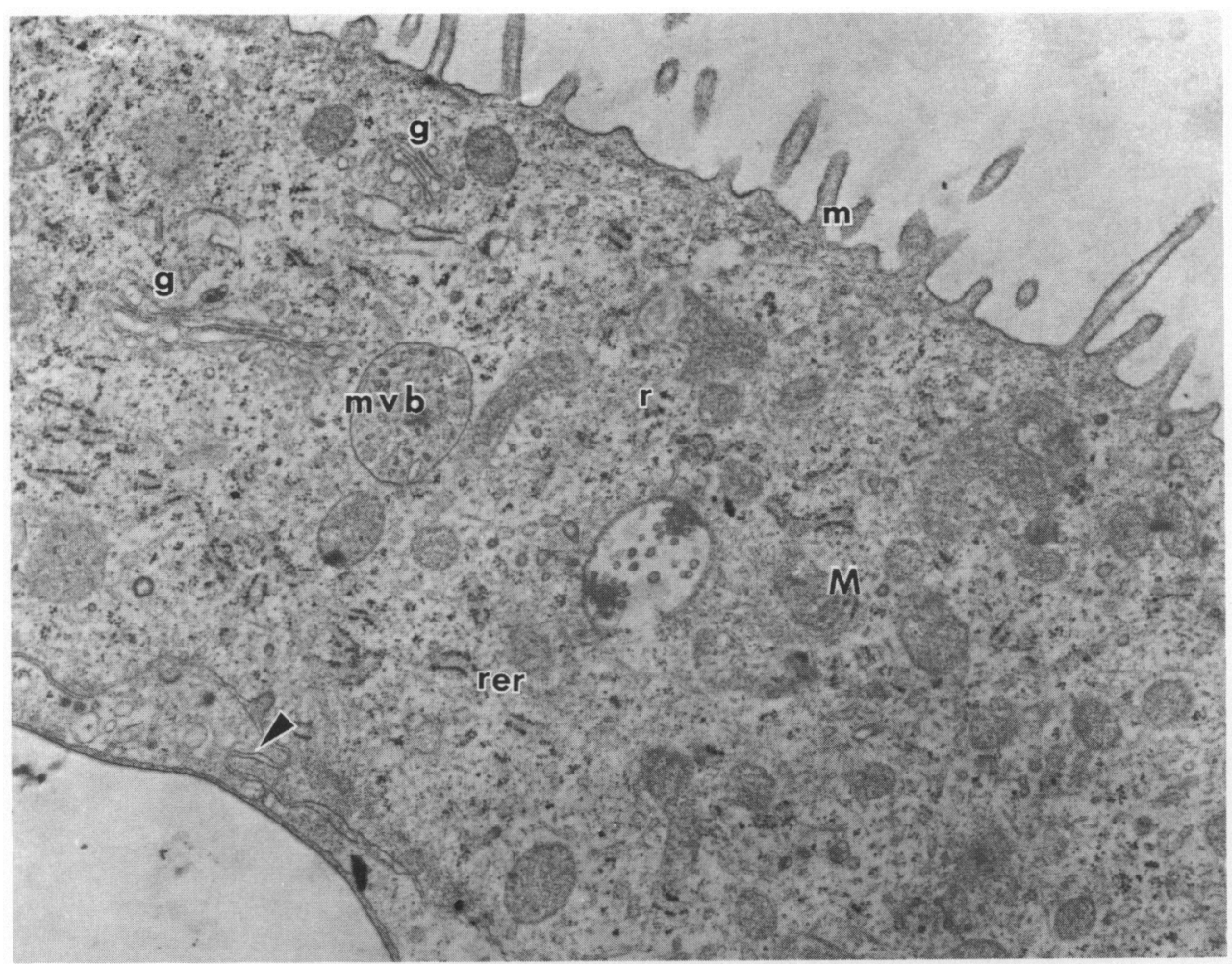

Fig. 4. Vertical section of an 8-day cultured secretory cell. Microvilli (m) are present at the luminal surface. The cytoplasm contains abundant rough endoplasmic reticulum (rer), Golgi complexes (g), polyribosomes ( $\mathrm{r}$ ), multivesicular bodies (mvb), and mitochondria (M). Arrowhead indicates the interdigitation between cells. $\times 14700$.

the free surface (Fig. 4). Neighbouring cells demonstrated frequent junctional complexes and interdigitation (Figs $4 \& 7$ a). In the sections studied, none of the 6-8-day cultured cells demonstrated the presence of cilia, and cells in these sections were identified by studying the predominance of the organelles within the cells.

The secretory cells of 6-8-day cultures showed one or two well-developed Golgi complexes with abundant rough endoplasmic reticulum and polyribosomes distributed throughout the cytoplasm (Figs $4 \& 5$ ). The vertical sections showed the presence of vesicles resembling multivesicular bodies near the Golgi complex. The secretory vesicles resembling those seen in intact oviduct epithelium were rarely observed in vertical sections of the cultured cells. Some of the horizontal sections displayed vesicles with characteristic lamellar inclusions in association with Golgi apparatus (Fig. 5).

The ciliated cells were recognized by the presence of less rough endoplasmic reticulum, a large number of mitochondria, free ribosomes, polyribosomes, and microtubules (Figs 6 \& 7). Occasionally, the 6-8-day cultured ciliated cells contained several basal bodies within the cytoplasm in association with a large number of smooth vesicles and microtubules (Fig. 6).

Thin sections of 4-day cell cultures demonstrated the presence of intact cilia in some cells (Fig. 7a), while in others they seemed to be replaced by microvilli (Fig. 7b). Some cells, probably ciliated, showed the presence of large vacuoles which contained debris and an occasional component of cilia (Fig. 7c). 


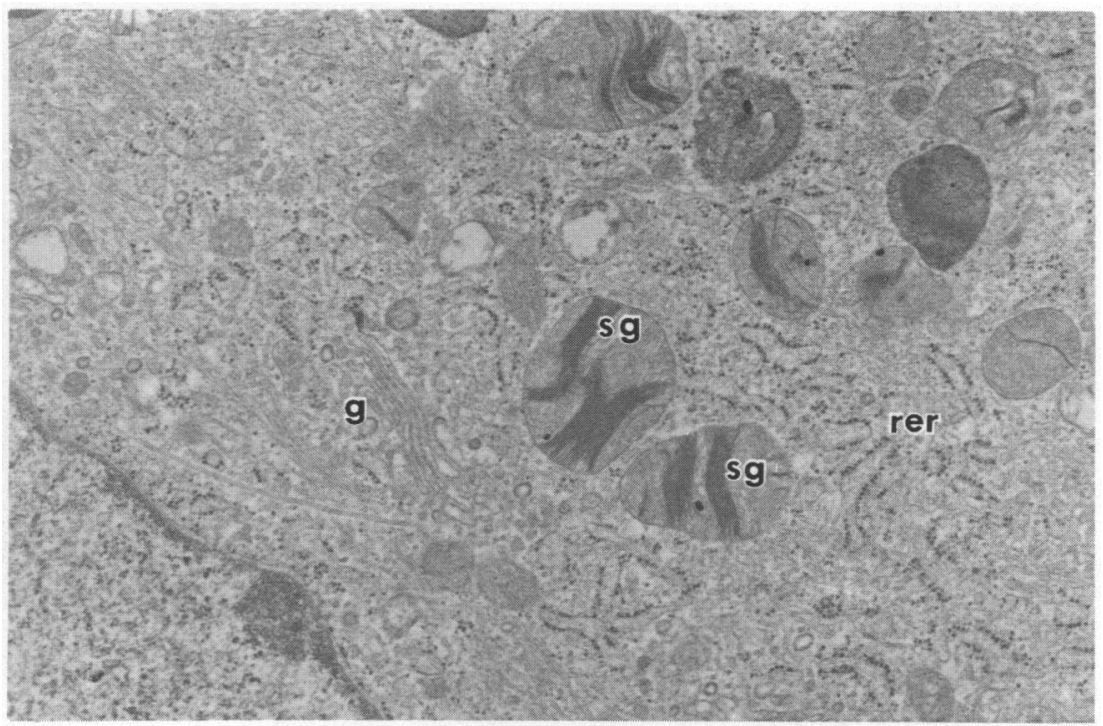

Fig. 5. Oblique section of an 8-day cultured secretory cell showing well developed Golgi complex (g), abundant rough endoplasmic reticulum (rer) and vesicles (sg) containing lamellar inclusions. $\times 16800$.

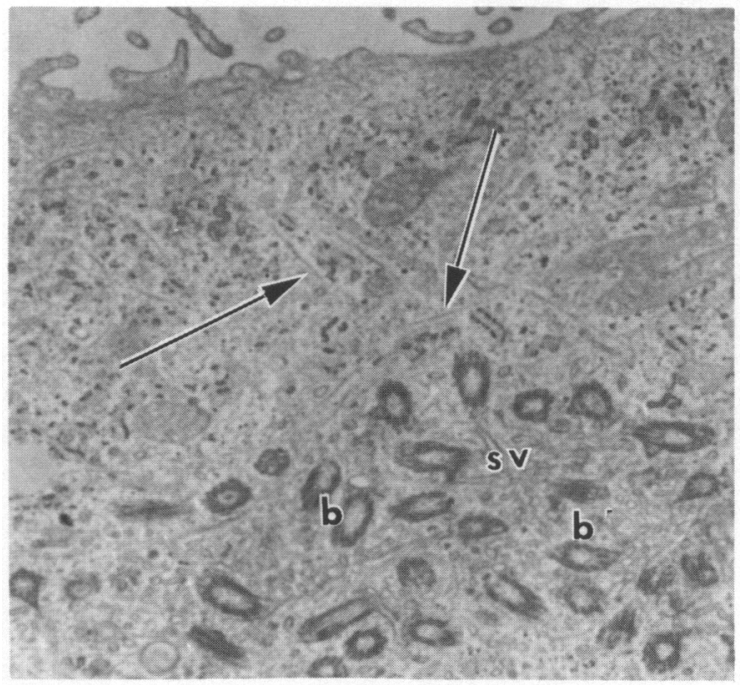

Fig. 6. Oblique section of an 8-day cultured ciliated cell. Note a number of basal bodies (b) within the cytoplasm associated with smooth vesicles (SV) and microtubules (arrows). $\times 11.000$. 

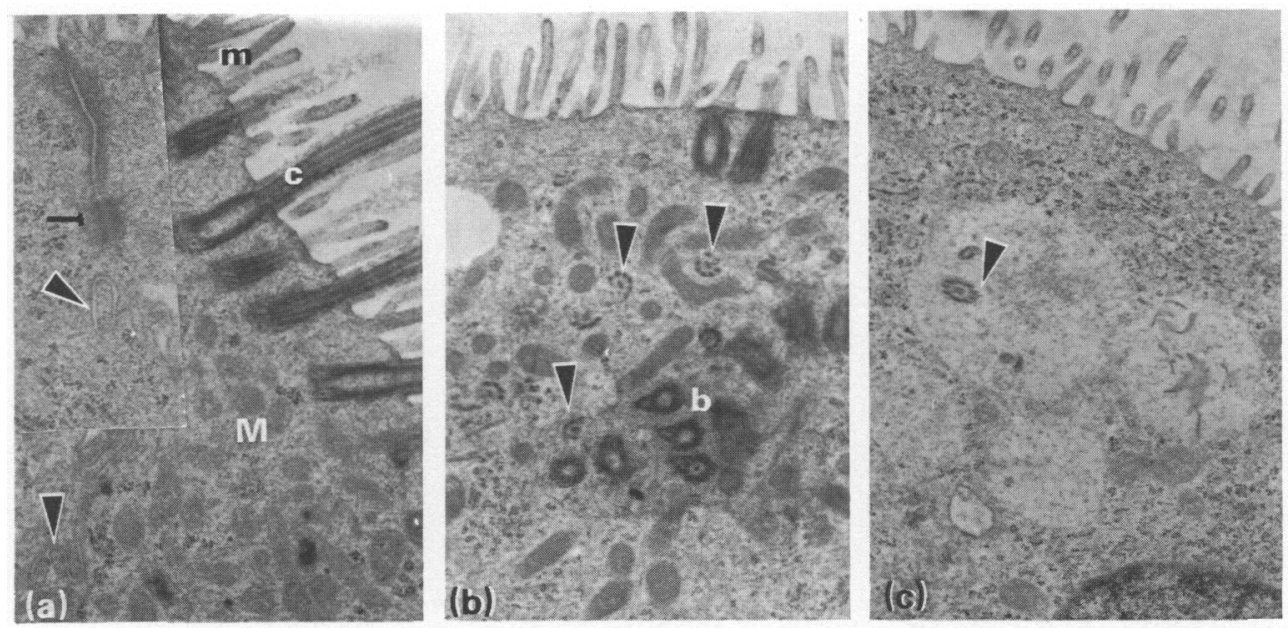

Fig. 7. Oblique sections of 4-day cultured ciliated cells: (a) a section showing several intact cilia (c), mitochondria (M) and microvilli (m). The inset shows the junctional complexes (arrows) and interdigitations (arrowhead). (b) A section showing remnants of cilia (airowhead) and basal bodies (b) in the cytoplasm. (c) A section showing large vacuoles containing debris and a remnant of a cilium (arrowhead). a, $\times 12000$; inset, $\times 18000 ; b, \times 11000 ; c, \times 9300$.
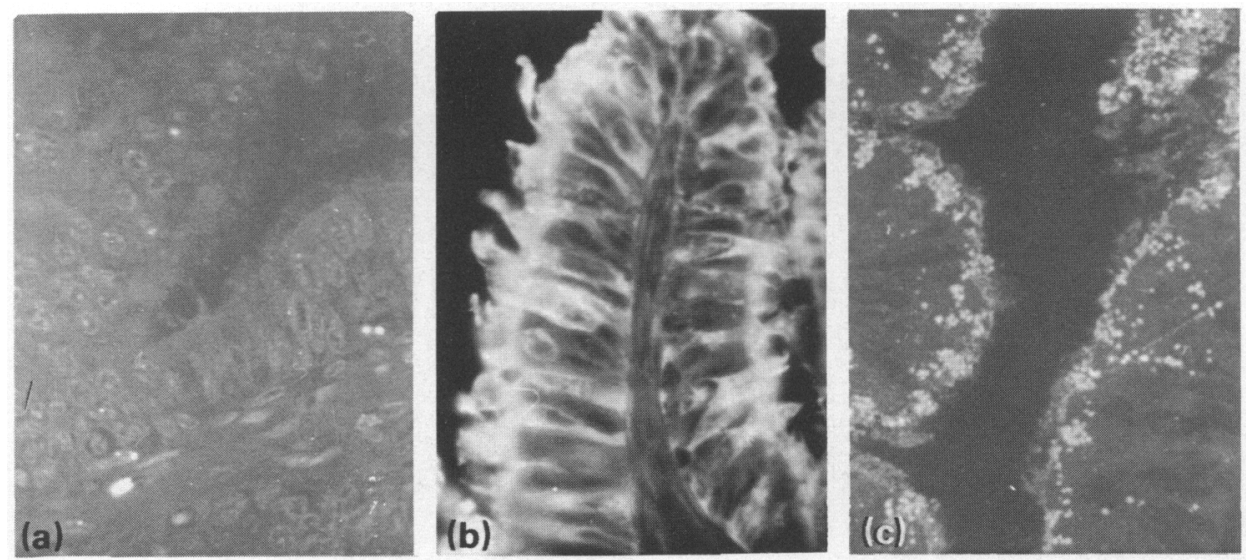

Fig. 8. Immunocytochemical tracing of the secretory proteins in the bovine oviduct epithelium (ampulla). (a) Control methacrylate section, $\times 880$; (b) experimental paraffin-wax section, $\times 920$; (c) experimental methacrylate section, $\times 1200$.

Immunocytological characterization of the epithelial cells

The cryostat, paraffin-wax and methacrylate sections of intact ampulla and isthmus were processed for the immunofluorescent tracing of the oviduct secretory proteins. All the three methods of sectioning indicated the presence of specific immunofluorescence in the epithelium (Fig. 8). The methacrylate sections showed specific immunofluorescence in the secretory cells in the form of discrete granules predominantly in the supranuclear region (Fig. 8c). The control sections 

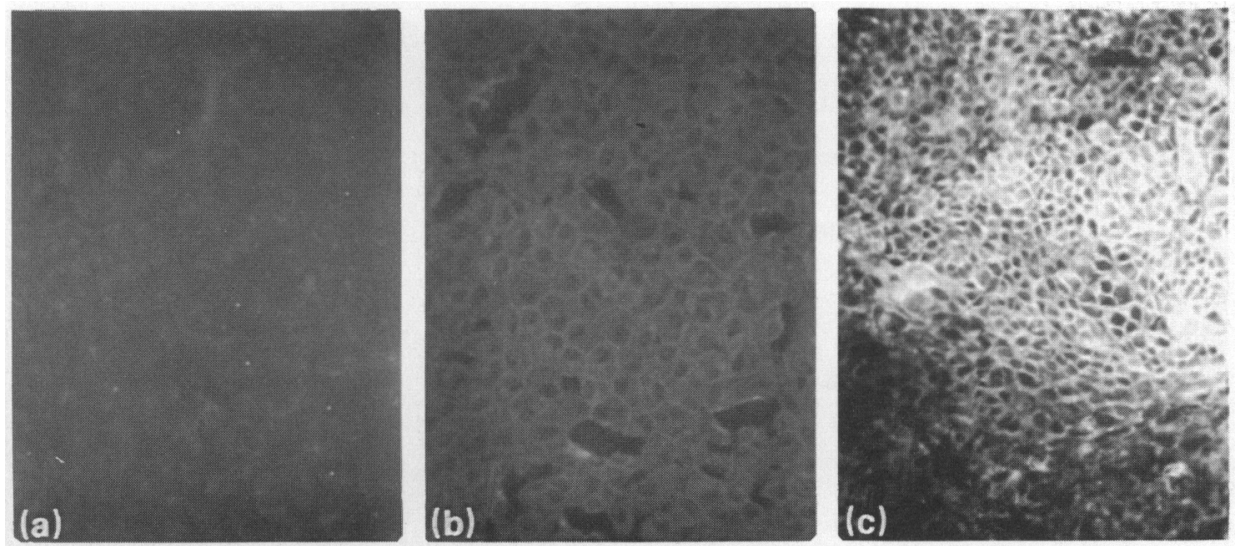

Fig. 9. Immunocytochemical tracing of secretory proteins in cultured oviduct epithelial cells: (a) control, $\times 200$; (b) experimental monolayer of corneal endothelial cells, layered with primary antiserum to bovine oviducal secretory proteins, $\times 200$; (c) experimental 8-day culture of oviduct epithelial cells, $\times 200$.
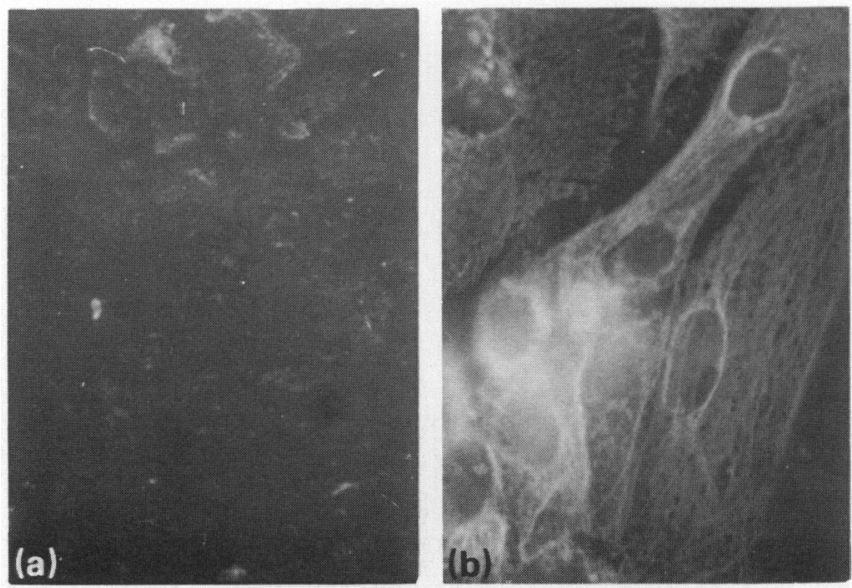

Fig. 10. Immunocytochemical tracing of keratin in cell cultures of bovine oviduct epithelial cells: (a) control, $\times 900 ;$ (b) experimental, $\times 1200$.

layered with preimmune rabbit serum instead of the primary antibody did not show any immunofluorescence (Fig. 8a).

Immunofluorescence tracing of the secretory proteins in the cultured epithelial cells indicated strong immunofluorescence in large patches of cells (Fig. 9c). The intensity of immunostaining varied in different cells. The lack of immunostaining in some cells may be because of poor secretory activity in the secretory cells or because the non-fluorescent cells were non-secretory ciliated cells. Monolayers of corneal endothelial cells lacked the specific immunofluorescence (Fig. 9b).

The oviduct epithelial cell cultures demonstrated the characteristic immunostaining of the cytoskeleton (Fig. 10b). 


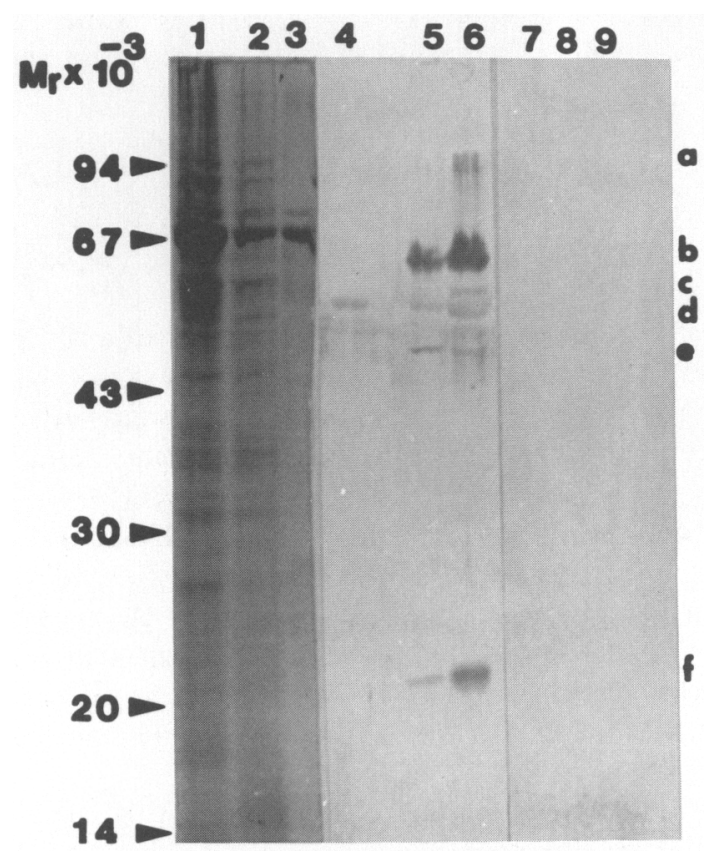

Fig. 11. SDS-PAGE of the proteins from the oviducal lumen (lanes 1 and 2) and of calf serum (lane 3). Lanes 4, 5, and 6 are immunoblots of the electrophoresed proteins which are first incubated with rabbit antiserum to oviducal fluid proteins absorbed with calf serum as the primary antiserum while lanes 7,8 and 9 are immunoblots of the electrophoresed proteins which are incubated with normal rabbit serum instead of the primary antiserum (see 'Materials and Methods'). The protein amounts in Lanes 1, 2, 3, 4, 5, 6, 7, 8 and 9 were 30, 8, 8, 8, 8, 30, 8 , 8 and $30 \mu \mathrm{g}$ respectively. a, b, c, d, e and f represent proteins of $M_{\mathrm{r}} 90000,70000,63000$, 58000,52000 and 20000 , respectively, recognized by the primary antiserum.

\section{Immunoblot studies}

The absorbed antiserum to the oviduct luminal proteins recognized distinctly 6 proteins from the oviduct fluid as indicated by the immunoblot (Fig. 11). The approximate molecular sizes of the proteins recognized by the antiserum are $90000,70000,63000,58000,52000$ and 20000 . In spite of repeated absorption of the antiserum with normal calf serum, the antiserum reacted faintly with a component of normal calf serum (Fig. 11, lane 4). However, the immunofluorescent tracing of the secretory proteins in the intact oviduct epithelium demonstrated specific immunofluorescence within the epithelial cells only with very negligible staining in the stroma (Figs $8 \mathrm{~b} \mathrm{\&} \mathrm{8c).}$

\section{Discussion}

This study shows a simple method of isolation of the epithelial cells from bovine isthmus or ampulla by incubation of the oviduct with $0 \cdot 1 \%$ collagenase in its lumen. The cells obtained by this method were ciliated and secretory cells without the contamination of stromal tissue. Attempts have been made in previous studies to isolate and culture bovine oviduct cells by scraping the mucous membrane with a scalpel and using the scrapings for cell culture (Witkowska, 1979a, b). This technique would probably introduce stromal and vascular cells in the cell culture, but Witkowska (1979a, b) did not include characterization of the cultured cells by electron microscopy 
or by immunocytology. The cells obtained by the present isolation technique contained only epithelial cells, as demonstrated with the phase-contrast, scanning and transmission electron microscopes, and by immunocytochemistry.

The isolated secretory and ciliated cells attached to the plastic substratum and proliferated to confluence in 10-12 days after seeding. All the cultured cells contained keratin filaments, the typical cytoskeletal structures of epithelial cells (Sun et al., 1979), as indicated by immunocytology.

Under culture conditions, the secretory and ciliated cells maintained most of the characteristic histoarchitecture described for the intact oviduct epithelium of the cow (Bjorkman \& Fredricsson, 1961; Dickey \& Hill, 1974; Nayak \& Wu, 1975; Uhrin, 1983; Uhrin \& Kliment, 1983a, b) but the cells in vitro had fewer secretory granules and increased presence of cytoskeletal elements. The increased visualization of cytoskeleton may be because of the changes introduced by spreading and change of cell shape due to in-vitro conditions. Similar cytoskeletal alterations have been observed in the cultured epididymal epithelial cell (Olson et al., 1983; Joshi, 1985).

The ciliated cells after attachment to the plastic, lost their cilia after 4-5 days in culture. It has been established that the ciliation and the secretory activity of the oviduct epithelium are induced by oestrogen (Fredricsson, 1959; Stone et al., 1980; Bareither \& Verhage, 1981; Odor et al., 1983). Nayak \& Wu (1975) did not observe any degeneration of cilia in the luteal phase of cows, while Uhrin \& Kliment (1983b) did observe stages of deciliation and the replacement of microvilli at the deciliated area and also the disintegration of membrane, filaments and the basal bodies within the cytoplasm of the cow oviduct epithelium.

In the present culture conditions, the cilia were maintained for only 4-5 days in cells which attached to the plastic. The electron microscopy of ciliated cells cultured for 4 days indicated the presence of a few intact cilia in some cells while in several other ciliated cells the cilia seemed to be replaced by microvilli. Some of the cells growing in vitro for 4 days showed the presence of large vacuoles containing debris. Occasionally some components of cilia could be identified in the vacuoles. The progressive loss of cilia in vitro by the attached ciliated cells in these culture conditions may not be entirely due to lack of oestrogen in the medium, because the ciliated cells which did not attach to plastic proliferated into balls of cells and maintained active ciliary movement in the same culture conditions for 4-5 days more than did those of the attached cells. The serum added to the culture medium was the only source of the steroid hormones to the cell culture. The effect of steroid hormones on the ciliary beating, secretory activity, and muscle contraction in oviduct explants growing in vitro has been examined (Bousquet, 1964; Rumery, 1969). The preliminary studies of Bousquet (1964) indicated stimulation of the rabbit oviduct epithelial activity by oestrogen while in mouse fetal oviduct explants, the oestrogen seemed to suppress ciliary activity and muscular contractions (Rumery, 1969). A more detailed morphological investigation is needed to understand the role of hormones on ciliogenesis and deciliation in cultured oviduct epithelial cells.

The secretory cells growing in vitro contained abundant rough endoplasmic reticulum and 2 or more well-developed Golgi complexes. The characteristic secretory vesicles with lamellar inclusions which were seen in intact secretory cells were evident only in horizontal sections but not observed in the vertical sections possibly because of the cell-flattening in vitro. Immunocytochemical tracing of the secretory proteins in the cultured cells showed specific immunofluoresence in intact secretory cells and in tissue culture cells indicating that, under the culture conditions, the secretory cells elaborated specific secretory products. The bovine oviduct fluid contained at least 6 protein components which were recognized by the absorbed antiserum, as indicated by the immunoblot studies. The antiserum, although extensively absorbed with normal calf serum, produced a faint reaction with a component of normal calf serum, but the immunofluorescent tracing studies using the absorbed antiserum indicated distinct specific immunostaining within the intact bovine epithelial cells.

Joshi (1987) has indicated that the secretory cells growing in vitro on reconstituted basement membrane became highly differentiated, maintaining the histoarchitecture and more closely resembling that of intact secretory cells, with secretory granules migrating to the apical 
plasmalemma. Experiments are in progress to study the role of steroid hormones on the secretory activity of the cells growing on the reconstituted basement membrane.

I thank Marianne Matthies for electron microscopic preparations and photography, and Julie Horn for assistance in the preparation of the manuscript.

\section{References}

Bareither, M.L. \& Verhage, H.G. (1981) Control of the secretory cell cycle in cat oviduct by estradiol and progesterone. Am. J. Anat. 162, 107-118.

Bjorkman, N. \& Fredricsson, B. (1961) The bovine oviduct epithelium and its secretory process as studied with the electron microscope and histochemical tests. Z. mikrosk. Anat. Forsch. 55, 500-513.

Boullant, A. \& Greig, A.S. (1973) Biological characterization of a cell line derived from the pig oviduct. In Vitro 9, 92-100.

Bousquet, J. (1964) Culture organotypique de fragments d'oviducte de ratte et de lapine. C.r. Séanc. Soc. Biol. Paris 158, 508-510.

Brenner, R.M. (1969) Renewal of oviduct cilia during menstrual cycle of the rhesus monkey. Fert. Steril. 20, 599-611.

Chang, M.C. (1951) Fertilizing capacity of spermatozoa deposited in the fallopian tube. Nature, Lond. 168, 697-698.

Dickey, J.F. \& Hill, J.R., Jr (1974) Histochemistry and electron microscopy of the bovine oviduct. In The Oviduct and its Functions, pp. 53-63. Eds A. D. Johnson \& C. W. Foley. Academic Press, New York.

Fazleabas, A.T. \& Verhage, H.G. (1986) The detection of oviduct specific proteins in the baboon. Biol. Reprod. $35,455-462$.

Feigelson, M. \& Kay, E. (1972) Protein patterns of rabbit oviduct fluid. Biol. Reprod. 6, 244-252.

Fredricsson, B. (1959) Proliferation of rabbit oviduct epithelium after estrogenic stimulation, with reference to the relationship between ciliated and secretory cells. Acta morphol. neerl. scand. 2, 193-202.

Gaunt, S.J. (1985) In vivo and in vitro cultured mouse preimplantation embryos differ in their display of teratocarcinoma cell surface antigen: possible binding of an oviduct factor. J. Embryol. exp. Morph. 88, $55-69$.

Hyde, B.A. \& Black, D.L. (1986) Synthesis and secretion of sulphated glycoproteins by rabbit oviduct explants in vitro. J. Reprod. Fert. 78, 8391.

Joshi, M.S. (1985) Isolation and cell culture of the epithelial cells of cauda epididymidis of the bull. Biol. Reprod. 33, 187-200.

Joshi, M.S. (1986) Ultrastructural study and the cell culture of the ciliated and secretory epithelium of the bovine oviduct. Anat. Rec. 214, 62A-63A, Abstr.

Joshi, M.S. (1987) Cell culture of bovine oviduct epithelial cells on matrigel substratum. Anat. Rec. 218, 69A-70A, Abstr.

Kapur, R.P. \& Johnson, L.V. (1985) An oviductal fluid glycoprotein associated with ovulated mouse ova and early embryos. Devl Biol. 112, 89-93.

Karnovsky, M.J. (1965) A formaldehyde-gluteraldehyde fixative of high osmolality for use in electron microscopy. J. Cell Biol. 27, 137A-138A, Abstr.

Kille, J.W. \& Hamner, C.E. (1973) The influence of oviduct fluid on the development of one-cell rabbit embryos in vitro. J. Reprod. Fert. 35, 415-423.

Laemmli, U.K. (1970) Cleavage of structural proteins during assembly of bacteriophage $\mathrm{T}_{\mathbf{4}}$. Nature, Lond. 227, 680-685.

Lowry, O.H., Rosebrough, N.J., Farr, A.L. \& Randall, R.J. (1951) Protein measurement with the folin phenol reagent. J. biol. Chem. 193, 265-275.

McDaniel, J.W., Scalzi, H. \& Black, D.L. (1968) Influence of ovarian hormones on histology and histochemistry of the bovine oviduct. J. Dairy Sci. 51, $754-761$.

Nayak, R.K. \& Wu, A.S.H. (1975) Ultrastructural demonstration of cilia and ciliary rootlets in mammalian uterine tube epithelium in different functional states. Am. J. vet. Res. 36, 1623-1630.

Nilsson, O. \& Hellstrom, K.E. (1957) Cell types identified in tissue cultures of epithelium of the rabbit fallopian tube. Acta obstet. gynaec. scand. 36, 340-346.

Odor, D.L. \& Blandau, R.J. (1985) Observation on the solitary cilium of rabbit oviductal epithelium: Its motility and ultrastructure. Am. J. Anat. 174, 437-453.

Odor, D.L., Gaddum-Rosse, P. \& Rumery, R.E. (1983) Secretory cells of the oviduct of the pig-tailed monkey, Macaca nemestrina, during the menstrual cycle and after estrogen treatment. Am. J. Anat. 166, 149-172.

Oliphant, G., Bowling, A., Eng, L.A., Keen, S. \& Randall, P.A. (1978) The permeability of the rabbit oviduct to proteins present in the serum. Biol. Reprod. 18, 516-520.

Oliphant, G., Reynolds, A.B., Smith, P.F., Ross, P.R. \& Marta, J.S. (1984) Immunocytochemical localization and determination of hormone-induced synthesis of the sulfated oviductal glycoproteins. Biol. Reprod. 31, 165-174.

Olson, G.E., Jonas-Davis, J., Hoffman, L.H. \& OrgebinCrist, M.-C. (1983) Structural features of cultured epithelial cells from the adult epididymis. J. Androl. 4, 347-360.

Rumery, R. (1969) Fetal mouse oviducts in tissue and organ cultures. Fert. Steril. 20, $149-162$.

Shapiro, S.S., Jentsch, J. \& Yard, A.S. (1974) Isolation of an acid glycoprotein from rabbit oviductal fluid and its association with the egg coating. J. Reprod. Fert. 40, 281-290.

Stone, S.L., Huckle, W.R. \& Oliphant, G. (1980) Identification and hormonal control of reproductive-tractspecific antigens present in rabbit oviductal fluid. Gamete Res. 3, 169-177. 
Sun, T-T., Shih, C. \& Green, H. (1979) Keratin cytoskeletons in epithelial cells of internal organs. Proc. natn. Acad. Sci. U.S.A. 79, 2813-2817.

Uhrin, V. (1983) The microscopic structure of oviduct epithelium during the estrous cycle of cows. Vet. Med. Praha 28, 145-156.

Uhrin, V. \& Kliment, J. (1983a) Submicroscopic changes in the secretory cells of oviduct epithelium in cows during the sexual cycle. Vet. Med. Praha 28, 199-209.

Uhrin, V. \& Kliment, J. (1983b) Submicroscopic changes of the ciliary cells of oviduct epithelium in cows during sexual cycle. Vet. Med. Paraha 28, 157-167.

Urzua, M.A., Stambaugh, R., Flickinger, G. \& Mastroianni, L., Jr (1970) Uterine and oviduct fluid protein patterns in the rabbit before and after ovulation. Fert. Steril. 21, 860-865.
Witkowska, E. (1979a) Reactivity of the epithelial cells of the bovine oviduct in vitro on the exogenic gonadotropic and steroid hormones. Part 1. The effect of gonadotropic and steroid hormones on the amount of lipids and activity of dehydrogenases. Folia histochem. cytobiol. 17, 225-238.

Witkowska, E. (1979b) Reactivity of the epithelial cells of the bovine oviduct in vitro on the exogenic gonado. tropic and steroid hormones. Part 2. The effect of gonadotropic hormones on the amount of glycogen and acid and alkaline phosphatases. Folia histochem. cytobiol. 17, 239-250.

Received 20 August 1987 